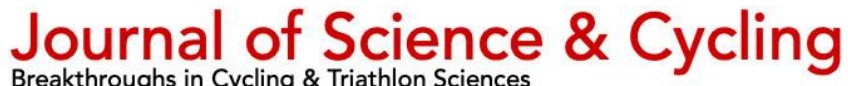

Review Article

\section{Applications of Muscle Oxygen Saturation Analysis in Cycling Performance Assessment: A Systematic Review}

\author{
Leonardo Cesanelli ${ }^{{ }^{*}}$, Berta Ylaite ${ }^{2}$, Nuno Leite ${ }^{3,4}$, and Julio Calleja-González 5 \\ 1 Department of Health Promotion and Rehabilitation, Lithuanian Sports University, Kaunas, Lithuania \\ 2 Institute of Sport Science and Innovations, Lithuanian Sports University, Kaunas, Lithuania \\ 3 Research Centre in Sports Sciences, Health Sciences and Human Development, CIDESD, CreativeLab Research \\ Community, Vila Real, Portugal. \\ 4 Dep. of Sports Sciences, Exercise and Health, University of Trás-os-Montes and Alto Douro, Vila Real, Portugal \\ 5 Laboratory of Analysis of Sports Performance-Department of Physical Education and Sport- Faculty of \\ Education-Sport Section. University of Basque Country, 01007, Vitoria-Gasteiz, Spain.
}

* Correspondence: Leonardo Cesanelli. mailto:cesaenelli.leonardo@gmail.com

Received: 22 november 2020; 29 June 2021; Published: 30 June 2021

\begin{abstract}
Purpose: Cycling performance is the result of the interplay among a wide range of variables. Different methodological approaches have been described during last 50 years in order to evaluate and understand cycling performance. Our main aim was to systematically review the applications of muscle oximetry in cycling performance assessment. Methods: A structured search was carried out following the PRISMA guidelines in MEDLINE®/PubMed and Scopus databases were searched with additional integration from external sources, between 1 February and 31 March 2020. To meet the inclusion criteria studies published from 2000 to 2020 and that applied muscle oxygen saturation analysis to investigate cyclists' performance were selected. This review included studies with experimental designs. There were no filters applied to the cyclists' level, sex, ray or age. Results: Starting from the 955 identified records, 21 items were finally included for the review. Three main investigation topics, related to application of muscle oximetry in cycling science, emerged: cycling performance analysis protocols $(n=8)$; training response and adaptations evaluation $(n=8)$ and impact of different pedaling cadences on cycling performance $(n=6)$. From the studies analyzing performance assessment protocols (38\%), emerged how only one threshold, also named breakpoint, seems to be recognizable through NIRS during cycling tests. Studies that focused on training metabolic adaptations (38\%) and cadence analysis (25.6\%) evidenced how NIRS device may represent a valid tool to analyze cyclists' metabolic adaptations and optimize pedaling cadence strategy. Conclusion: Despite the wide range of applications and promising data emerging from NIRS studies, further investigations evaluating cycling performance are needed to better delineate possible, laboratory and field, applications, and methodologies.
\end{abstract}

Keywords: NIRS; endurance; performance analysis; cycling.

\section{Introduction}

In order to quantify different level of athletes' performance, several methods and indexes have been identified, developed, and used for research or in-field application purposes (Castronovo et al., 2013). In particular cycling performance, with the interplay of different variables such as physiological, biomechanical, mechanical,

(c) 2021 Author., licensee JSC. This is an Open Access article distributed under the terms of the Creative Commons Attribution License ((http://creativecommons.org/licenses/by/4.0/) which permits unrestricted use, distribution, and reproduction in any medium, provided the original work is properly cited. 
and psychological, have been widely investigated from different perspective and through different methodologies (Passfield et al. 2017, Jobson et al., 2009). These phenomena describe a constant improvement of performance understanding and optimization as well as an increase in variables, indicators, and investigation methods (Castronovo et al., 2013). This gradual content increase has given rise to doubts and questions regarding to applicability, reliability, and functionality of one or the other variable or method to analyze, predict or optimize performance (Jobson et al., 2009).

From a physiological point of view, the interplay of aerobic and anaerobic power, metabolic and mechanical efficiencies constitute the basics of endurance performance optimization, with skeletal muscle mitochondria representing the common biological factor shared across these variables (Gabriel and Zierath, 2017). Physiological indicators of endurance performance have been recognized as a combination of athletes' maximal rate of whole-body oxygen $\left(\mathrm{O}_{2}\right)$ consumption $\left(\mathrm{VO}_{2} \mathrm{max}\right)$, a valid exercise intensity threshold and an index of bioenergetic efficiency during exercise (Gabriel and Zierath, 2017; Joyner and Coyle, 2008). In this sense, different authors observed how skeletal muscle respiratory potential may also plays a fundamental role in biological control of endurance performance potential, as in most of our daily activities, and in particular exercise, the energy for muscle work sustainability derives from the oxidation of glucose and lipids in muscle fibers, culminating in oxidative phosphorylation at the mitochondrial respiratory chain (Jacobs et al., 2013; Batterson et al., 2020). Thus, the aim to develop reliable methodologies and devices able to investigate muscle oxidative metabolism during exercise represented an innovative research field with several potential advantages for exercise physiologists (Perrey and Ferrari, 2018; Ferrari and Quaresima, 2012). Chance et al. in 1992 published the first application of muscle oximetry in athletes investigating the degree to which $\mathrm{O}_{2}$ supply and utilization occurred during exercise and hemoglobin/myoglobin $(\mathrm{Hb} / \mathrm{Mb})$ deoxygenation after exercise, during recovery time through near infra-red spectroscopy (NIRS). From there, additional studies investigated the applications of NIRS in different sport science fields, as documented by different literature reviews (Perrey and Ferrari, 2018; Ferrari and Quaresima, 2012; Hamaoka et al., 2011).

Although whole body oxygen consumption $\left(\mathrm{VO}_{2}\right)$ has been widely investigated and historically considered one of the main variable to evaluate the integrated performance of the respiratory, cardiovascular, and skeletal muscle components of the $\mathrm{O}_{2}$ pathways from ambient air to the mitochondria of the skeletal muscles, the impossibility to discriminate between the exercising muscles and the rest of the body, and between muscles engaged in the examined exercise, represent an intrinsic limitation of this methodology (Hoppeler and Weibel, 1998; Aliverti, 2016).

Muscle oximetry through NIRS allows for acquiring data on muscle tissue oxygenation and hemodynamic changes according to the oxygen-dependent characteristics of acquired near infrared light. The NIRS signals are thus the result of the weighted average of the $\mathrm{O}_{2}$ saturations of the heme groups of the $\mathrm{Hb}$ in the vascular bed (small arteries, arterioles, capillaries, venules, small veins) and of the $\mathrm{Mb}$ heme groups in muscle fibers (Grassi and Quaresima, 2016). Changes in absorbance in the region near 850 $\mathrm{nm}$ are ascribed to oxygenated $\mathrm{Hb} / \mathrm{Mb}$, and absorbance in the region near $760 \mathrm{~nm}$ is attributed to deoxygenated $\mathrm{Hb} / \mathrm{Mb}$. Mostly, a ratio of absorbance at $850 / 760 \mathrm{~nm}$ is used to describe oxygen saturation and the ratio of absorbance at $850 /(850+760) \mathrm{nm} \times 100$ to identify the tissue oxygenation/saturation index (TSI) (Perrey and Ferrari, 2018; Ferrari and Quaresima, 2012; Hamaoka et al., 2011; Neary, 2004). Different reviews underlined the wide range of applications of NIRS in sport science and, in particular on muscle tissue metabolism investigations (Perrey and 
Ferrari, 2018; Ferrari and Quaresima, 2012; Neary, 2004; Quaresima, Lepanto and Ferrari, 2003).

To assess the physiological variables affecting cycling performance, gas exchanges dynamics, blood lactate dynamics and/or functional threshold power evaluation represent probably the most investigated aspects (Passfield et al. 2017; Atkinson et al., 2003; Jeukendrup and Martin, 2001).

However, as mentioned, the understanding of muscle respiratory potential may provide additional insights and potentially cover a key role in cycling performance assessment, as NIRS can offer insights into the physiological adaptations to different training or performance conditions characterized by increased $\mathrm{O}_{2}$ requirements. Therefore, different researchers, trainers and cycling technicians investigated application of muscle oximetry on cycling science (Perrey and Ferrari, 2018).

Thus, our aim was to systematically review the applications of muscle oximetry on cycling performance analysis and optimization.

\section{Materials and Methods}

The present article is a systematic review focusing on the applications of muscle oxygen saturation analysis in cycling performance assessment and it was conducted following the Preferred Reporting Items for Systematic Review and MetaAnalyses (PRISMA) guidelines (Moher et al., 2009). Moreover, PEDro scale was used to evaluate whether the selected randomized controlled trials were scientifically sound (9$10=$ excellent, $6-8=$ good, $4-5=$ fair, and $<4=$ poor) (Maher et al., 2003). When the score was unavailable on the PEDro database, articles were rated independently by two researchers. Papers with poor PEDro score were excluded.

\section{Literature search}

A computerized systematic literature search was performed (February 2020 to March 2020), while no year restriction was applied to the search strategy using two online databases (MEDLINE®/PubMed and
Scopus), to retrieve articles pertaining to cycling performance analysis through muscle oximetry. A hand search of relevant reviews and additional research was performed to obtain possible articles missed by the database search. An additional search, performed through Google Scholar online database, has been successively done to include a cycling specialized journal (J Sci (ycling) not indexed in the aforementioned databases. Search terms included a mix of Medical Subject Headings (MeSH) and freetext words for key concepts as follows. A combination of keywords addressing (("Muscle" [MeSH Terms] OR "tissue") AND "oxygen" [MeSH Terms] AND "saturation"[All Fields])) OR ("NIRS") [MeSH Terms] OR ("Oximetry") AND ("sport" [MeSH Terms] OR "athlete" OR "cycling" OR "cyclist") [All Fields]) AND ("performance"[MeSH Terms] OR "test" OR "analysis") [All Fields]) were used. All titles and abstracts from the search were crossreferenced to identify duplicates and any potential missing studies. Titles and abstracts were then screened for a subsequent full-text review. The search for published studies was independently performed by two authors (2000 and 2020) and disagreements were resolved through discussion. The search results were downloaded and filtered in EndNote software (X8; Clarivate Analytics, New York, USA). The search concluded on March 31st, 2020.

\section{Inclusion and exclusion criteria}

We formed eligibility criteria using the PICO (Population, Interventions, Comparators, Outcomes) strategy as represented in Table 1 (Methley et al., 2014). To meet the inclusion criteria for this systematic review, studies published in the English language, investigating humans "in vivo", published from 2000 to 2020 and that applied muscle oxygen saturation analysis to investigate cycling performance were selected. Studies conducted on children $(<12$ years old), on different endurance athletes (from cyclists or triathletes), on injured individuals, on disabled people, on use of 
supplements and/or drugs or clinical studies on diseased individuals have been excluded. Observational studies controlled clinical trials (CCTs), meta-analysis, systematic reviews, or meta-regressions and consensus conferences were firstly included in the research as random controlled trials (RCTs) with randomization at any level and, subsequently, subjected to the screening procedures (Figure 1).

Table 1. Summary of inclusion criteria following the PICO approach

\begin{tabular}{cc}
\hline Parameter & Inclusion Criteria \\
\hline Participants & $\begin{array}{c}\text { Cyclists }(>12 \text { years old; included } \\
\text { triathletes) }\end{array}$ \\
\hline Intervention & $\begin{array}{c}\text { Application of NIRS for muscle } \\
\text { oxygen saturation analysis }\end{array}$ \\
\hline Comparison & Any \\
\hline Outcome & $\begin{array}{c}\text { Validation of methods, thresholds } \\
\text { investigations, impact of training } \\
\text { strategies or athletes monitoring, } \\
\text { recovery or warm up strategies } \\
\text { investigation, any outcome } \\
\text { related to intervention strategies. }\end{array}$ \\
\hline
\end{tabular}

Study selection and data extraction

Following the removal of duplicate studies from the different search engines, inclusion or exclusion of the remaining articles was performed by applying the above criteria on the title and abstract to determine eligibility in a preliminary independent screening. Selected papers were then read in full to finalize eligibility or exclusion. A summary of this process is outlined in Figure 1.

A standardized form was utilized to extract and collate data, including study design and aim, characteristics of participants, investigation methods, representativeness of the study sample and results. Data for each included study were extracted and checked by two reviewers (authors). For each article, authors, date of publication, sample size, participant characteristics (age, sex, body mass), NIRS device, exercise protocol, intervention or testing protocol, muscle(s) assessed, and a summary of the main findings were extracted and are reported in Table 2. Subsequently, disagreements were resolved through discussion until a consensus was achieved. Experiments were clustered manually, through a customized Microsoft Excel spreadsheet used also for the data extraction procedures, and according to the type of test used to assess the effects on the considered variables.

\section{Methodological quality assessment}

To assess the methodological quality of the selected studies, the Physiotherapy Evidence Database (PEDro) scale (Table 3) and a modified version of the Downs and Black checklist (Table 4) were used (Maher et al., 2003; Downs and Black, 1998; Glasziou, Vandenbroucke and Chalmers, 2004). The PEDro scale represents a reliable and objective tool that helps to identify which of the randomized controlled trials from the same areas of physiotherapy practice are likely to be externally (criteria 1) and internally (criteria 2 to 9) valid and could have enough statistical information to make their results interpretable (criteria 10 and 11) (Maher et al., 2003). Each article was independently assessed twice by two reviewers (authors) using the 11-item checklist to yield a maximum score of 10 (the sum of awarded points for criteria 2 to 11) and discrepant results were resolved through a consensus meeting. Points are only awarded when a criterion is clearly satisfied and when criterion one, which relates to external validity, is not used to calculate the PEDro score. From previous studies (Maher et al., 2003; Moseley et al., 2011), a score of 9 10 on the PEDro scale was considered "high quality", scores of 5-8 were considered "moderate quality", and studies that scored below 5 were considered "low quality".

The Downs and Black checklist were adapted according to Fox et al., with utilization of a selection of 10 of the 27 criteria that logically applied to all the types of studies included in this review (Fox et al., 2014). The maximum possible total score was 10 . No study was excluded. 


\section{Results}

A total of 21 studies met the inclusion criteria (Jacobs et al., 2013; Batterson et al., 2020; Boone et al., 2010; Crum et al., 2017; Iannetta et al., 2017; Racinais, Buchheit and Girard, 2014; Raleigh, Donne and Fleming, 2018; Van der Zwaart et al., 2016; Zorgati et al., 2015; Faiss et al., 2013; Gendron et al., 2016; Hamlin et al., 2010; Hopker, O'Grady and Pageaux, 2017; Neary, McKenzie and Bhambhani, 2002; Sperlich et al., 2015; Turner et al., 2013; Wittekind et al., 2012; Formenti et al., 2019; Shastri Table 4. Downs and Black modified checklist quality assessment et al., 2019; Skovereng, Ettema and van Beekvelt, 2016; Takaishi et al., 2002) and were included in this current systematic review. The predefined search strategy yielded a preliminary pool of 955 papers. Removal of duplicates and screening of titles resulted in a selection of final 122 papers. After a second screening for eligibility, based first on abstract and then on full text, a provisional list of 39 published studies emerged from the research. The full texts of 39 articles were retrieved in detail by two authors (authors) leading to 30 possible studies selected for eligibility. A final screening made during data extraction, after a careful additional review (authors), led to a final inclusion of 21 articles (Jacobs et al., 2013; Batterson et al., 2020; Boone et al., 2010; Crum et al., 2017; Iannetta et al., 2017; Racinais, Buchheit and Girard, 2014; Raleigh, Donne and Fleming, 2018; Van der Zwaart et al., 2016; Zorgati et al., 2015; Faiss et al., 2013; Gendron et al., 2016; Hamlin et al., 2010; Hopker, O'Grady and Pageaux, 2017; Neary, McKenzie and Bhambhani, 2002; Sperlich et al., 2015; Turner et al., 2013; Wittekind et al., 2012; Formenti et al., 2019; Shastri et al., 2019; Skovereng, Ettema and van Beekvelt, 2016; Takaishi et al., 2002) (Figure 1). The studies included in this systematic review involved a total of 356 participants ( $\mathrm{n}=337$ males and $\mathrm{n}=19$ females). The number of participants in each trial ranged from 6 to 50 with a mean sample size of 15.5 individuals. The included studies targeted healthy cyclists ranging from amateur to elite categories: $n=6510$, (Boone et al., 2010; Raleigh, Donne and Fleming, 2018;
Zorgati et al., 2015; Hamlin et al., 2010; Turner et al., 2013); sub-elite: $\mathrm{n}=1606$, (Batterson et al., 2020; Crum et al., 2017; Racinais, Buchheit and Girard, 2014; Van der Zwaart et al., 2016; Gendron et al., 2016; Hopker, O'Grady and Pageaux, 2017; Neary, McKenzie and Bhambhani, 2002; Sperlich et al., 2015; Wittekind et al., 2012); amateurs: $\mathrm{n}=1304$, (Van der Zwaart et al., 2016; Zorgati et al., 2015; Faiss et al., 2013; Shastri et al., 2019; Skovereng, Ettema and van Beekvelt, 2016; Takaishi et al., 2002). According to the studies' aims, three main topics of investigation emerged. 1) Different studies aimed to evaluate and/or validate testing protocols or methods or to compare muscle oxygen saturation parameters to traditionally physiological variables acquired to analyze cyclists' performance and physical condition (Batterson et al., 2020; Boone et al., 2010; Crum et al., 2017; Iannetta et al., 2017; Racinais, Buchheit and Girard, 2014; Raleigh, Donne and Fleming, 2018; Van der Zwaart et al., 2016; Zorgati et al., 2015). 2) Another main topic was represented by the evaluation of the impact of different training strategies on muscle oxygen saturation dynamics (Faiss et
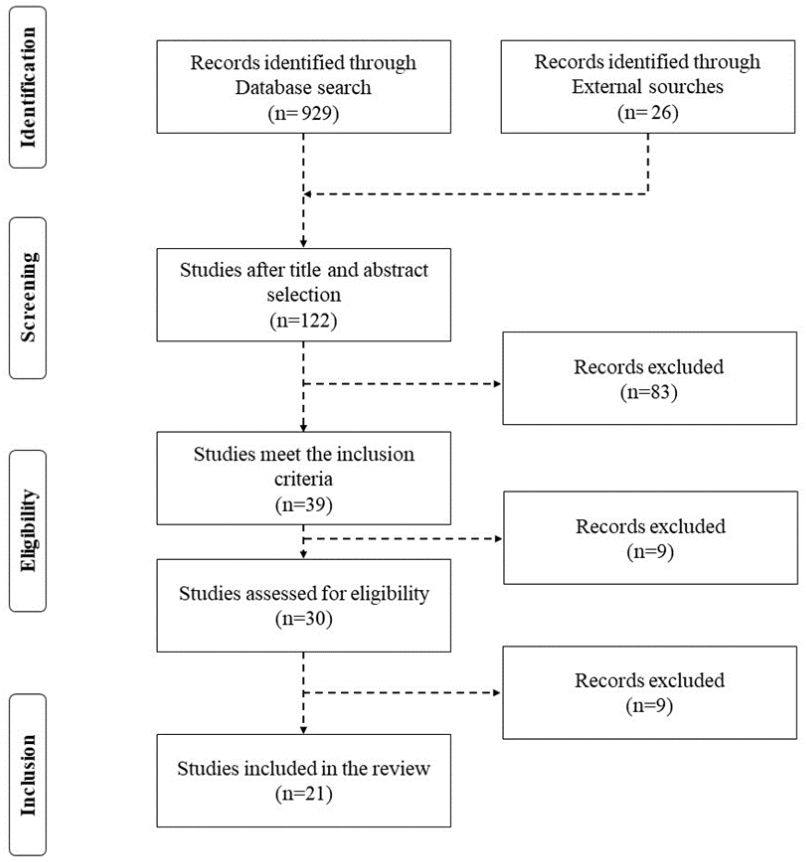

Figure 1. PRISMA selection flow chart

al., 2013; Gendron et al., 2016; Hamlin et al., 2010; Hopker, O'Grady and Pageaux, 2017; 
Neary, McKenzie and Bhambhani, 2002; Sperlich et al., 2015; Turner et al., 2013; Wittekind et al., 2012). 3) Additional field is represented by the evaluation of changes in pedaling cadences at constant or different workloads (Jacobs et al., 2013; Zorgati et al., 2015; Formenti et al., 2019; Shastri et al., 2019; Skovereng, Ettema and van Beekvelt, 2016; Takaishi et al., 2002). Most studies placed the NIRS devices on dominant leg vastus lateralis and/or vastus medialis muscle of the dominant leg. Nine different brands of NIRS devices were used throughout these investigations. All reviewed studies scored a moderate mean PEDro score of $5.2 \pm 0.9$ and a moderate to high mean score of $7.8 \pm 0.7$ of Downs and Black modified checklist (Table 3 and Table 4).

\section{Cycling performance evaluation protocols}

Different investigations focused on the analysis of reliability and applicability of NIRS for cycling performance evaluation as summarized in Figure 2 (Batterson et al., 2020; Boone et al., 2010; Crum et al., 2017; Iannetta et al., 2017; Racinais, Buchheit and Girard, 2014; Raleigh, Donne and Fleming, 2018; Van der Zwaart et al., 2016; Zorgati et al., 2015). Crum and colleagues (2017) investigated reliability of a NIRS device (Moxy) analyzing cycling performance during two repeated incremental exercise protocols. Muscle oxygen saturation acquired data [change in total $\mathrm{Hb}(\Delta \mathrm{tHb})$, change in muscle oxygen saturation $(\Delta \mathrm{SmO})]$ were compared between the two tests, performed in the same conditions, and with whole-body oxygen consumption $\left(\dot{\mathrm{V}}_{2}\right)$ and heart rate (HR) variables. Muscle oxygen saturation [i.e., change in muscle oxygen saturation $(\triangle \mathrm{SmO} 2)]$ seemed to be a valid indicator of cycling performance during incremental exercise compared with $\mathrm{V}_{2}$ and $\mathrm{HR}$, however at higher intensities tissue ischemia or increased legs movement may represent confounding factors leading to difficulties in the interpretation of the results. In addition, total hemoglobin showed low variation during the incremental exercise protocol and thus, did not appear to be a valid muscle oxygenation indicator. Differently, Boone et al. aimed to compare the possible divergences in in deoxy[ $\mathrm{Hb}+$ $\mathrm{Mb}$ ] pattern during two different exercise protocols: step (40 Wx3 min-1) and ramp (35 $\mathrm{W} \times$ min-1.), observing how the sigmoid pattern of deoxy $[\mathrm{Hb}+\mathrm{Mb}]$ seemed not to be influenced by testing protocol or exercise condition (Boone et al., 2010). Ramp exercise testing was further selected as a study protocol to investigate and locate the breakpoint of muscle oxygenation, in reference to the first and second ventilatory thresholds by Racinais, Buchheit and Girard, (2014). The authors recognized only one muscle oxygenation threshold, in which muscle oxyhemoglobin $\left(\mathrm{O}_{2} \mathrm{Hb}\right)$ displayed a non-linear decrease and muscle deoxyhemoglobin $(\mathrm{HHb})$ increase was attenuated. These changes in muscle oxygenation dynamics occurred proximally to the second ventilatory threshold. If the changes in muscle oxygenation reported by Racinais, Buchheit and Girard (2014) occurred at intensities significantly higher than first ventilatory threshold, close to respiratory compensation point, the results of van der Zwaard et al. (2016) showed a different pattern with high correlations between muscle oxygenation breakpoint and first ventilatory threshold. This discrepancy might be attributed to methodological differences such as thresholds determination or the utilization of a ramp protocol (Racinais, Buchheit and Girard, 2014) vs. an incremental step protocol (Zwaard et al., 2016). Raleigh, Donne and Fleming (2018) aimed to compare tissue saturation index (TSI) and ventilatory threshold as noninvasive endurance performance indicators with lactate threshold during graded incremental exercise to volitional exhaustion. Power output at TSI threshold and blood lactate threshold were not significantly different ( $255 \pm 35$ vs. $249 \pm 30 \mathrm{~W}$ ) suggesting a possible link between aerobic-anaerobic transition and limitations in $\mathrm{O}_{2}$ delivery. However, the poor correlations displayed by the two variables $(\mathrm{r}=0.55, \mathrm{ICC}=0.54$ and $95 \%$ LoA of +67 and -54 W) suggested possible other factors as main possible 
influencer. Batterson et al. (2020) aimed to compare predictive models of endurance performance evaluation analyzing a $25 \mathrm{~km}$ time-trial performance. The comparison was between a traditional model represented by whole body oxygen consumption, a fatigue threshold and different indexes of exercise efficiency with skeletal muscle oxidative potential. Interestingly, skeletal muscle $\mathrm{O}_{2}$ consumption $\left(\mathrm{mVO}_{2}\right)$ recovery rates resulted a better predictor $(92.7 \%$ of time to completion variance) than $\dot{\mathrm{V}}_{2} \max , \% \dot{\mathrm{V}} \mathrm{O}_{2 \max }$ and cycling economy combination $(76.2 \%$ of time to completion variance) of the $25-\mathrm{km}$ time trial cycling performance. Iannetta et al. (2017) further investigated the correlation between respiratory compensation point and breakpoint of deoxygenated hemoglobin during ramp incremental exercise and repeatability of this measure. The experiment, two ramp identical test sessions separated by $48 \mathrm{~h}$ in which gas exchanges and muscle oxygen saturation data were acquired, resulted in similar occurrence in time of respiratory compensation point and breakpoint of deoxygenated hemoglobin (test $1 \dot{\mathrm{VO}}_{2}: 3.38 \pm 0.40$ vs. $3.49 \pm 0.52 \mathrm{~L} \mathrm{~min}{ }^{-}$; test $2 \dot{\mathrm{VO}}_{2}: 3.38 \pm 0.44$ vs. $3.48 \pm 0.45 \mathrm{~L} \mathrm{~min}^{-1}$ ) with no significant differences between tests.

\section{Training programs impact evaluation}

Another topic of interest resulted to be the evaluation of muscular metabolic adaptations during or after different cycling training strategies (Figure 2) (Faiss et al., 2013; Gendron et al., 2016; Hamlin et al., 2010; Hopker, O'Grady and Pageaux, 2017; Neary, McKenzie and Bhambhani, 2002; Sperlich et al., 2015; Turner et al., 2013; Wittekind et al., 2012). Neary (2004), examined central (cardiorespiratory responses) and peripheral (muscle deoxygenation) adaptations after 3 weeks of endurance training, through an incremental test and a $20 \mathrm{~km}$ time trial performance before and after the training protocol. The authors observed how, the athletes improved their peak power output and $\mathrm{V}_{2} \mathrm{O}_{2}$ ax during the incremental test but with unchanged patterns of muscle deoxygenation. The athletes were significantly faster in the $20 \mathrm{~km}$ time trial after training protocol, showing non-significant changes in $\dot{\mathrm{V}}_{2}, \mathrm{HR}$ or $\mathrm{O}_{2}$ pulse output while mean muscle deoxygenation resulted significantly lower after intervention. The investigation of Hopker, O'Grady and Pageaux (2017) focused on the analysis of changes in gross cycling efficiency (GE) and muscle oxygen uptake $\left(\mathrm{mV} \mathrm{O}_{2}\right)$ during a $2 \mathrm{~h}$ steady-state cycling exercise performed at $60 \%$ of maximal minute power output. GE significantly declined during the experiment, conversely, $\mathrm{mV}_{2}$ increased in the latest phases (90-120 $\mathrm{min}$ ). The authors stated how the increase in $\mathrm{mV}_{2} \mathrm{O}_{2}$ may provide evidence of progressive mitochondrial contractile inefficiency during prolonged exercise performed at medium-high intensities. Other interventions focused on the effect of hypoxia on muscle oxygenation during cycling performance. Hamlin and colleagues (2010) evaluated the effect of 90-min sessions intermittent hypoxic exposure protocol (7:3 min hypoxia to normoxia) for 10 days on 20 $\mathrm{km}$ time trial performance. The cyclists involved in the study were randomly assigned to intervention or control group and then evaluated (20-km time trial) before and after the training protocol. The intervention group showed an elevated muscle oxyhemoglobin during the final stages of the trial as well as systemic oxygen saturation $\left(\mathrm{SaO}_{2}\right)$ compared with baseline, however this was not translated into improved performance compared with control.

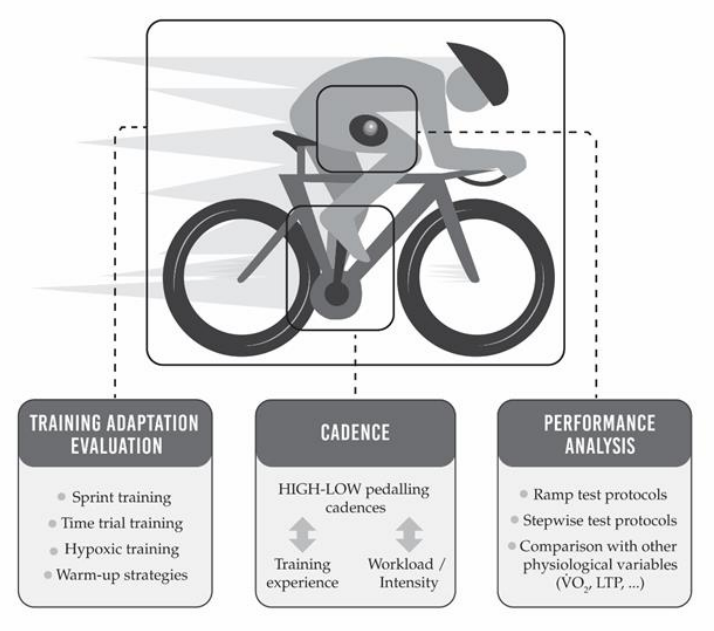

Figure 2. Summary of outcomes 
Sperlich et al. (2015) investigated the acute effect of splenic contraction induced by repeated apneas protocol on $4-\mathrm{km}$ time trial performance. The cyclists, participants of the study were asked to perform a $4-\mathrm{km}$ time trial with and without four prior maximal bouts of apnea interspersed with 2 minutes of recovery. The results showed a reduction in splenic contraction after the repeated apneas protocol but without any difference in terms of muscle oxygen saturation, performance power output and final time trial result. Turner et al. (2013) determined the effect of inspiratory loading on limb locomotor (vastus lateralis) and respiratory muscle (the serratus anterior) deoxygenation during 6 min trials of which first three minutes performed at $80 \% \mathrm{VO}_{2}$ max and last 3 minutes in different conditions: moderate inspiratory loading, heavy inspiratory loading, and maximal exercise. The results showed how an increase in respiratory muscle load can produce increases in muscle deoxy $[\mathrm{Hb}+\mathrm{Mb}]$ and thus may indicate a reduction in oxygen delivery and/or increased oxygen extraction by the active muscles. Faiss et al. (2013) analyzed muscle perfusion through NIRS before and after a sprint training protocol $(8$ cycling sprint repeated sessions performed in hypoxic conditions or normoxic conditions, respectively 3000 and $485 \mathrm{~m}$ sprints) on repeated sprint ability tested till exhaustion (10-s sprint, work-to-test ratio 1:2). The results showed similar average power output between all sprints, but hypoxic training group increased the number of sprints to exhaustion and total hemoglobin variations $(\Delta \mathrm{tHb})$ during repeated sprint ability test compared to pre-intervention. The study of Gendron and colleagues (2016) involved cross-country mountain bikers to investigate the possible central and peripheral metabolic effects of 8 sessions supra-maximal interval training program. After the intervention, the athletes improved their time trial performances ( $-4.2 \%$ time to complete) and both pulmonary sub-maximal oxygen consumption and deoxyhemoglobin decreased significantly $(-4.7 \%$ and $-21.9 \%)$ during maximal aerobic power test. Wittekind et al. (2012), investigated the effects on muscle oxygenation and metabolism of different intensity warm up strategies on all-out sprint cycling performance. Warm up strategies consisted in moderate, heavy, or severe and the sprint on a 30s all-out performance. Mean power during the sprint was lower following severe compared to moderate warm up but not different between heavy and moderate. The $[\mathrm{HHb}]$ kinetics during exercise where not different among conditions although the time delay before $[\mathrm{HHb}]$ increased was shorter for severe versus moderate warm up.

\section{Impact of different pedaling cadences}

An additional investigation field emerging from our review was related to the impact of pedaling cadence on muscle oximetry dynamics during cycling (Figure 2) (Jacobs et al., 2013; Zorgati et al., 2015; Formenti et al., 2019; Shastri et al., 2019; Skovereng, Ettema and van Beekvelt, 2016; Takaishi et al., 2002). Zorgati and colleagues (2015) compared muscle oxygenation during a cycling test until exhaustion at a fixed intensity corresponding to $90 \%$ of the peak oxygen uptake but at different cadences (40 and $100 \mathrm{rpm}$ ), in cyclists of different level. The comparison between élite and untrained athletes resulted in significantly higher muscle deoxygenation ( $\triangle$ deoxy $[\mathrm{Hb}+\mathrm{Mb}])$, $\Delta \mathrm{tHb}$ and time performed until exhaustion at $40 \mathrm{rpm}$ compared to $100 \mathrm{rpm}$ in the seconds one, suggesting how high aerobic fitness may represent the key factor between cadence and performance and that may allow a better regulation between $\mathrm{mVO}_{2}$ and muscle oxygen delivery $\left(\mathrm{mQO}_{2}\right)$ following changes in pedaling cadence. Takaishi and colleagues (2002) evaluated the impact of cycling experience and pedal cadence on NIRS acquired parameters, reporting how, after fitting muscle oxygen saturation and blood volume data against crank angles, the reordered NIRS changes demonstrated a temporary increase at the crank angle corresponding to the relaxation phase of the working muscles, during high cadence exercise. Jacobs et al. (2013), Skovereng et al. (2019) and Formenti et al. (2016), investigated muscle oxygen saturation during cycling at 
constant high intensity workload at different cadences. The results of Jacobs et al. (2013) suggested a cadence of $60 \mathrm{rpm}$ as more advantageous than higher cadences for moderately trained athletes. Both, in the experiments of Skovereng, Ettema and van Beekvelt (2016), and Formenti and colleagues (2019), higher cadences resulted in muscle deoxygenation and $\mathrm{mVO}_{2}$ increases or TSI decreases, suggesting that skeletal muscle oxygenation is relatively more affected by high cadences when exercise intensity is medium-high. Shastri et al. (2019) analyzed the possible effects of different cadences at two different exercise intensities $(70 \%$ and $90 \%$ of ventilatory threshold), reporting how despite increased cardiopulmonary and metabolic response during high intensity cycling test, no significant differences emerged between the two intensity protocols, with a trend similar to that described in the previously mentioned studies.

\section{Discussion}

The present work represents the first review aiming to systematically identify the applications of muscle oximetry specifically for cycling athlete evaluation. Overall, muscle oximetry application in cycling can be considered a relatively new application field with only 2 studies published before 2010 $(9.5 \%)$, with applications covering training strategies evaluation and performance analysis as the main investigated topics.

The analysis of the possible interconnections between commonly investigated performance indicators as ventilatory thresholds (VT1 and VT2), lactic acid threshold and muscle oxygenation threshold, or breakdown, or location of the last one in relation to the previous, represented one of the main research aims.

Published data show how only one threshold, also named breakpoint, is recognizable through NIRS during cycling tests and it may be related to changes in muscle fiber type recruitment during exercise (Boone et al., 2010; Racinais, Buchheit and Girard, 2014; Van der Zwaart et al., 2016). However, despite NIRS muscle oximetry derived parameters seem to represent robust markers of skeletal muscle oxidative capacity, differences in the methodological approaches (Racinais, Buchheit and Girard, 2014; Van der Zwaart et al., 2016) or different study conditions led to discordant results and difficulties to assume possible overlaps occurrence with other thresholds, or to consider NIRS data as possible substitute of other investigation techniques (Boone et al., 2010; Racinais, Buchheit and Girard, 2014; Van der Zwaart et al., 2016). Anyway, data as that published by Batterson et al. (2020), in which skeletal muscle respiration resulted a more complete explanatory variable compared to traditional performance indicators, represent a promising perspective in this context that could be further confirmed with future investigations. This, also considering the possible advantages of wireless devices for NIRS muscle oximetry evaluations, potentially depict a practical and reliable solution to evaluate athletes' performance in different contexts and with a flexible testing frequency. However, additional clarifications on the interrelationship between muscle oxygenation, pulmonary gas exchanges, blood lactate, HR, and muscle activation responses, as well as more studies covering testing procedures in different contexts from the lab environment, are still required.

An additional common aim resulted to be the analysis of the muscle oxygenation dynamics at different pedaling cadences. Three main considerations emerging from these investigations are that: i) experienced/élite athletes may benefit of high cadence pedaling techniques as well as low cadences without significant changes in performance output and physiological effort, while on the contrary, ii) unexperienced cyclists should prefer lower cadences, iii) in general, NIRS proved to be a valid and interesting technique to investigate these aspects (Jacobs et al., 2013; Zorgati et al., 2015; Wittekind et al., 2012; Formenti et al., 2019; Shastri et al., 2019; Skovereng, Ettema and van Beekvelt, 2016). Taken together, NIRS muscle oximetry seemed to provide valid data in order to analyze and support 
pedaling technique and/or strategy, future studies may consider similar study designs applied to cycling biomechanics evaluation (e.g., impact of cleats position on different muscle oxygen saturation dynamics) and/or in high-level cycling performance contexts as track cycling disciplines and/or time trials competitions, where a tool to support competition strategy set-up (e.g., pacing strategies or gearing) may represent a useful upgrade for coaches and team staff.

Another considerable facet is that NIRS as a lightweight, miniaturized, and wireless technology may represent a quick, noninvasive and continuous measurement tool suitable for field-based evaluations. This may allow investigation also in population as the young athlete, avoiding invasive and discomfortable tests as can be blood lactate sampling or gas exchanges evaluations. However, despite this can be considered one of the main advantages of this evaluation technique, all the studies investigating training strategies, selected in the present review, were structured in laboratory conditions (Neary, 2004; Faiss et al., 2013; Gendron et al., 2016; Hamlin et al., 2010; Hopker, O'Grady and Pageaux, 2017; Neary, McKenzie and Bhambhani, 2002; Sperlich et al., 2015; Turner et al., 2013).

This may represent a limit to generate useful feedbacks and information for in field sport scientists or athletes' staff aiming to find ready-to-apply solutions to analyze and improve athletes' performance and to produce evidence-based training schedules.

In addition, it remains unclear whether the responses in NIRS for one muscle site could be representative enough to quantify internal loading and guide training in athletes (Perrey and Ferrari, 2018).

The actual gap between laboratory research and in field application studies may be due to the relatively short time elapsed since first applications and quantity of acquired data of NIRS and cycling science.

\section{Conclusions}

Despite a wide range of applications and promising data emerging from literature, additional works are needed to better understand application modalities, application fields and reliability of NIRS data on cycling performance analysis and optimization. In particular there seems to be a lack of in-field investigations, which could be fundamental to delineate and study protocols to acquire reliable and useful additional information to optimize cyclist performance. Cycling performance assessment through NIRS techniques appears to have great potential, future studies may prove additional data and insights related to both laboratory and infield research settings.

Funding: This research received no external funding

Conflicts of Interest: The authors declare no conflict of interest.

\section{References}

1. Aliverti, A. (2016). The respiratory muscles during exercise. Breathe, 12(2), 165-168.

2. Atkinson, G., Davison, R., Jeukendrup, A., \& Passfield, L. (2003). Science and cycling: Current knowledge and future directions for research. Journal of Sports Sciences, 21(9), 767-787.

https://doi.org/10.1080/026404103100010209 7

3. Batterson, P. M., Norton, M. R., Hetz, S. E., Rohilla, S., Lindsay, K. G., Subudhi, A. W., \& Jacobs, R. A. (2020). Improving biologic predictors of cycling endurance performance with near-infrared spectroscopy derived measures of skeletal muscle respiration: E pluribus unum. Physiological Reports, 8(2). https://doi.org/10.14814/phy2.14342

4. Boone, J., Koppo, K., Barstow, T. J., \& Bouckaert, J. (2010). Effect of exercise protocol on deoxy[ $\mathrm{Hb}+\mathrm{Mb}]$ : Incremental step versus ramp exercise. Medicine and Science in Sports and Exercise, 42(5), 935942.

https://doi.org/10.1249/MSS.0b013e3181c0ec ea

5. Castronovo, A. M., Conforto, S., Schmid, M., Bibbo, D., \& D'Alessio, T. (2013). How to assess performance in cycling: The multivariate nature of influencing factors and related indicators. Frontiers in Physiology,

https://doi.org/10.3389/fphys.2013.00116 
6. Crum, E. M., O'Connor, W. J., Van Loo, L., Valckx, M., \& Stannard, S. R. (2017). Validity and reliability of the Moxy oxygen monitor during incremental cycling exercise. European Journal of Sport Science, 17(8), 1037-1043.

https://doi.org/10.1080/17461391.2017.13308 99

7. Jacobs, R. D., Berg, K. E., Slivka, D. R., \& Noble, J. M (2013). The effect of cadence on cycling efficiency and local tissue oxygenation. Journal of Strength and Conditioning Research, 27(3), 637-642. https://doi.org/10.1519/JSC.0b013e31825dd2 24

8. Downs, S. H., \& Black, N. (1998). The feasibility of creating a checklist for the assessment of the methodological quality both of randomised and non-randomised studies of health care interventions. Journal of Epidemiology and Community Health, 52(6), 377-384.

9. Faiss, R., Léger, B., Vesin, J.-M., Fournier, P.E., Eggel, Y., Dériaz, O., \& Millet, G. P. (2013). Significant molecular and systemic adaptations after repeated sprint training in hypoxia. PloS One, 8(2), e56522. https://doi.org/10.1371/journal.pone.0056522

10. Ferrari, M., \& Quaresima, V. (2012). Near Infrared Brain and Muscle Oximetry: From the Discovery to Current Applications: Journal of Near Infrared Spectroscopy. https://doi.org/10.1255/jnirs.973

11. Formenti, F., Dockerill, C., Kankanange, L., Zhang, L., Takaishi, T., \& Ishida, K. (2019). The Effect of Pedaling Cadence on Skeletal Muscle Oxygenation During Cycling at Moderate Exercise Intensity. International Journal of Sports Medicine, 40(5), 305-311. https://doi.org/10.1055/a-0835-6286

12. Fox, A. S., Bonacci, J., McLean, S. G., Spittle, M., \& Saunders, N. (2014). What is normal? Female lower limb kinematic profiles during athletic tasks used to examine anterior cruciate ligament injury risk: a systematic review. Sports Medicine (Auckland, N.Z.), 44(6),

$815-832$. https://doi.org/10.1007/s40279-014-0168-8

13. Gabriel, B. M., \& Zierath, J. R. (2017). The Limits of Exercise Physiology: From Performance to Health. Cell Metabolism, 25(5), 1000-1011. https://doi.org/10.1016/j.cmet.2017.04.018
14. Glasziou, P., Vandenbroucke, J., \& Chalmers, I. (2004). Assessing the quality of research. BMJ : British Medical Journal, 328(7430), 3941.

15. Grassi, B., \& Quaresima, V. (2016). Nearinfrared spectroscopy and skeletal muscle oxidative function in vivo in health and disease: a review from an exercise physiology perspective. Journal of biomedical optics, 21(9), 091313.

16. Hamaoka, T., McCully, K. K., Niwayama, M., \& Chance, B. (2011). The use of muscle near-infrared spectroscopy in sport, health and medical sciences: Recent developments. Philosophical Transactions. Series A, Mathematical, Physical, and Engineering Sciences, 369(1955), 4591-4604. https://doi.org/10.1098/rsta.2011.0298

17. Hamlin, M. J., Marshall, H. C., Hellemans, J., \& Ainslie, P. N. (2010). Effect of intermittent hypoxia on muscle and cerebral oxygenation during a $20-\mathrm{km}$ time trial in elite athletes: A preliminary report. Applied Physiology, Nutrition, and Metabolism, 35(4), 548-559. https://doi.org/10.1139/H10-044

18. Hopker, J. G., O'Grady, C., \& Pageaux, B. (2017). Prolonged constant load cycling exercise is associated with reduced gross efficiency and increased muscle oxygen uptake. Scandinavian Journal of Medicine \& Science in Sports, 27(4), 408-417. https://doi.org/10.1111/sms.12673

19. Hoppeler, H., \& Weibel, E. R. (1998). Limits for oxygen and substrate transport in mammals. Journal of Experimental Biology, 201(8), 1051-1064.

20. Iannetta, D., Qahtani, A., Mattioni Maturana, F., \& Murias, J. M. (2017). The near-infrared spectroscopy-derived deoxygenated haemoglobin breaking-point is a repeatable measure that demarcates exercise intensity domains. Journal of Science and Medicine in Sport, 20(9), 873-877. https://doi.org/10.1016/j.jsams.2017.01.237

21. Jeukendrup, A. E., \& Martin, J. (2001). Improving cycling performance: How should we spend our time and money. Sports Medicine (Auckland, N.Z.), 31(7), 559-569. https://doi.org/10.2165/00007256200131070-00009

22. Jobson, S. A., Passfield, L., Atkinson, G., Barton, G., \& Scarf, P. (2009). The analysis and utilization of cycling training data. 
Sports Medicine (Auckland, N.Z.), 39(10), 833-844. https://doi.org/10.2165/11317840000000000-00000

23. Joyner, M. J., \& Coyle, E. F. (2008). Endurance exercise performance: The physiology of champions. The Journal of Physiology, 586(Pt 1), 35-44. https://doi.org/10.1113/jphysiol.2007.143834

24. Maher, C. G., Sherrington, C., Herbert, R. D., Moseley, A. M., \& Elkins, M. (2003). Reliability of the PEDro scale for rating quality of randomized controlled trials. Physical Therapy, 83(8), 713-721.

25. Methley, A. M., Campbell, S., ChewGraham, C., McNally, R., \& Cheraghi-Sohi, S. (2014). PICO, PICOS and SPIDER: A comparison study of specificity and sensitivity in three search tools for qualitative systematic reviews. BMC Health Services Research, 14, 579. https://doi.org/10.1186/s12913-014-0579-0

26. Moher, D., Liberati, A., Tetzlaff, J., Altman, D. G., \& PRISMA Group. (2009). Preferred reporting items for systematic reviews and meta-analyses: The PRISMA statement. Annals of Internal Medicine, 151(4), 264-269, W64. https://doi.org/10.7326/0003-4819-1514-200908180-00135

27. Moseley, A. M., Herbert, R. D., Maher, C. G., Sherrington, C., \& Elkins, M. R. (2011). Reported quality of randomized controlled trials of physiotherapy interventions has improved over time. Journal of Clinical Epidemiology, 64(6), 594-601. https://doi.org/10.1016/j.jclinepi.2010.08.009

28. Neary, J. P. (2004). Application of near infrared spectroscopy to exercise sports science. Canadian Journal of Applied Physiology $=$ Revue Canadienne De Physiologie Appliquee, 29(4), 488-503. https://doi.org/10.1139/h04-032

29. Neary, J. P., McKenzie, D. C., \& Bhambhani, Y. N. (2002). Effects of short-term endurance training on muscle deoxygenation trends using NIRS. Medicine and Science in Sports and Exercise, 34(11), 1725-1732. https://doi.org/10.1097/00005768-20021100000006

30. Passfield, L., Hopker, J. G., Jobson, S., Friel, D., \& Zabala, M. (2017). Knowledge is power: Issues of measuring training and performance in cycling. Journal of Sports Sciences, 35(14), 1426-1434. https://doi.org/10.1080/02640414.2016.12155 04

31. Performance and cycling efficiency after supra-maximal interval training in trained cross-country mountain bikers. (n.d.). Retrieved 5 May 2020, from http://ijass.sports.re.kr/_PR/view/?aidx=1689 $8 \&$ bid $=1302$

32. Perrey, S., \& Ferrari, M. (2018). Muscle Oximetry in Sports Science: A Systematic Review. Sports Medicine (Auckland, N.Z.), 48(3), 597-616. https://doi.org/10.1007/s40279-017-0820-1

33. Quaresima, V., Lepanto, R., \& Ferrari, M. (2003). The use of near infrared spectroscopy in sports medicine. The Journal of Sports Medicine and Physical Fitness, 43(1), 1-13.

34. Racinais, S., Buchheit, M., \& Girard, O. (2014). Breakpoints in ventilation, cerebral and muscle oxygenation, and muscle activity during an incremental cycling exercise. Frontiers in Physiology, 5. https://doi.org/10.3389/fphys.2014.00142

35. Raleigh, C., Donne, B., \& Fleming, N. (2018). Association between different NonInvasively Derived Thresholds with Lactate Threshold during graded incremental exercise. International Journal of Exercise Science, 11(4), 391-403.

36. Shastri, L., Alkhalil, M., Forbes, C., El-Wadi, T., Rafferty, G., Ishida, K., \& Formenti, F. (2019). Skeletal muscle oxygenation during cycling at different power output and cadence. Physiological Reports, 7(3), e13963. https://doi.org/10.14814/phy2.13963

37. Skovereng, K., Ettema, G., \& van Beekvelt, M. C. P. (2016). Oxygenation, local muscle oxygen consumption and joint specific power in cycling: The effect of cadence at a constant external work rate. European Journal of Applied Physiology, 116(6), 12071217. https://doi.org/10.1007/s00421-0163379-x

38. Sperlich, B., Zinner, C., Pfister, R., Holmberg, H.-C., \& Michels, G. (2015). Repeated apneainduced contraction of the spleen in cyclists does not enhance performance in a subsequent time-trial. European Journal of Applied Physiology, 115(1), 205-212. https://doi.org/10.1007/s00421-014-3003-x

39. Takaishi, T., Ishida, K., Katayama, K., Yamazaki, K., Yamamoto, T., \& Moritani, T. (2002). Effect of cycling experience and pedal 
cadence on the near-infrared spectroscopy parameters. Medicine and Science in Sports and Exercise, 34(12), 2062-2071. https://doi.org/10.1097/00005768-20021200000030

40. Turner, L. A., Tecklenburg-Lund, S., Chapman, R. F., Stager, J. M., Duke, J. W., \& Mickleborough, T. D. (2013). Inspiratory loading and limb locomotor and respiratory muscle deoxygenation during cycling exercise. Respiratory Physiology \& Neurobiology, 185(3), 506-514. https://doi.org/10.1016/j.resp.2012.11.018

41. van der Zwaard, S., Jaspers, R. T., Blokland, I. J., Achterberg, C., Visser, J. M., den Uil, A. R., Hofmijster, M. J., Levels, K., Noordhof, D. A., de Haan, A., de Koning, J. J., van der Laarse, W. J., \& de Ruiter, C. J. (2016). Oxygenation Threshold Derived from NearInfrared Spectroscopy: Reliability and Its
Relationship with the First Ventilatory Threshold. PloS One, 11(9), e0162914. https://doi.org/10.1371/journal.pone.0162914

42. Wittekind, A., Cooper, C. E., Elwell, C. E., Leung, T. S., \& Beneke, R. (2012). Warm-up effects on muscle oxygenation, metabolism and sprint cycling performance. European Journal of Applied Physiology, 112(8), 31293139. https://doi.org/10.1007/s00421-0112262-Z

43. Zorgati, H., Collomp, K., Boone, J., Guimard, A., Buttelli, O., Mucci, P., Amiot, V., \&Prieur, F. (2015). Effect of pedaling cadence on muscle oxygenation during high-intensity cycling until exhaustion: A comparison between untrained subjects and triathletes. European Journal of Applied Physiology, 115(12), 2681-2689. https://doi.org/10.1007/s00421-015-3235-4 


\section{Annexes}

Table 2. Summary of findings of included studies investigating muscle oximetry application in cycling science

\begin{tabular}{|c|c|c|c|c|c|c|c|}
\hline Application site & Study (year) & Sample size & Study aim & Protocol & Main outcomes & $\begin{array}{l}\text { Variable } \\
\text { measured }\end{array}$ & Device \\
\hline Vastus Lateralis & $\begin{array}{l}\text { Batterson et al. } \\
(2020)^{7}\end{array}$ & $\begin{array}{l}24 \text { cyclists }(\mathrm{M}, 36.8 \pm 11.6 \\
\text { years, } 76.6 \pm 9.8 \mathrm{~kg})\end{array}$ & $\begin{array}{l}\text { To compare the predictive validity of } \\
\text { the often-referenced traditional model } \\
\text { of human endurance performance } \\
\text { versus measures of skeletal muscle } \\
\text { oxidative potential in relation to } \\
\text { endurance cycling performance. }\end{array}$ & $\begin{array}{l}\text { Incremental ramp test to } \\
\text { volitional fatigue followed } \\
\text { by a verification max test } 10 \\
\text { min and then after } 60 \mathrm{~m} \text { from } \\
\text { the first test a } 25-\mathrm{km} \text { time } \\
\text { trial, which commenced } 60 \\
\text { min. }\end{array}$ & $\begin{array}{l}\text { Maximal rates of skeletal muscle } \\
\text { respiration more completely } \\
\text { explained cycling endurance } \\
\text { performance than even the best } \\
\text { combination of traditional } \\
\text { variables. }\end{array}$ & $\begin{array}{l}\Delta \mathrm{tHb} \\
\Delta \mathrm{HHb} \\
\Delta \mathrm{O} 2 \mathrm{Hb} \\
\mathrm{mVO} 2\end{array}$ & $\begin{array}{l}\text { Oxymon } \\
\text { MKIII }\end{array}$ \\
\hline Vastus Lateralis & Boone et al. $(2010)^{22}$ & $\begin{array}{l}10 \text { competitive cyclists } \\
(\mathrm{M}, 19 \pm 2 \text { years, } 77 \pm 8 \\
\mathrm{kg})\end{array}$ & $\begin{array}{l}\text { To investigate whether the sigmoid } \\
\text { pattern of deoxy[Hb }+\mathrm{Mb}] \text { during } \\
\text { incremental exercise is specific to non- } \\
\text { steady-state conditions. }\end{array}$ & $\begin{array}{l}2 \text { testing procedures (ramp } \\
\text { and step) of incremental } \\
\text { cycle exercises on an } \\
\text { ergometer. }\end{array}$ & $\begin{array}{l}\text { Similar sigmoid pattern of } \\
\text { deoxygenation to both } \\
\text { incremental exercise protocols. }\end{array}$ & $\Delta \mathrm{HHb}$ & Oxiplex TS \\
\hline Vastus Lateralis & Crum et al. $(2017)^{23}$ & $\begin{array}{l}10 \text { highly trained cyclists } \\
(\mathrm{M}, 23 \text { years range } 16-30, \\
71 \pm 10 \mathrm{~kg})\end{array}$ & $\begin{array}{l}\text { To investigate the reliability of the } \\
\text { Moxy during cycling and assess the } \\
\text { correlations between measurements of } \\
\text { whole-body } \mathrm{O}_{2} \text { consumption }\left(\mathrm{VO}_{2}\right) \text { and } \\
\text { heart rate }(\mathrm{HR})\end{array}$ & $\begin{array}{ll}\text { Incremental, } & \text { stepwise } \\
\text { cycling protocol on two } \\
\text { occasions. }\end{array}$ & $\begin{array}{l}\text { The Moxy resulted a reliable } \\
\text { device to measure } \mathrm{SmO} 2 \text { at low } \\
\text { to moderate intensities. THb has } \\
\text { low variation during exercise } \\
\text { and does not appear to be a valid } \\
\text { indicator of muscle oxygenation. }\end{array}$ & $\begin{array}{l}\Delta \mathrm{tHb}, \\
\Delta \mathrm{SmO} 2\end{array}$ & Moxy \\
\hline Vastus Lateralis & Faiss et al. $(2013)^{29}$ & $\begin{array}{l}50 \text { moderately trained } \\
\text { cyclists }(\mathrm{M}, 35 \pm 6.7 \\
\text { years, } 75 \pm 6.9 \mathrm{~kg})\end{array}$ & $\begin{array}{l}\text { To examine repeated sprint training in } \\
\text { hypoxia could enhance repeated sprint } \\
\text { ability performed in normoxia via } \\
\text { improved glycolysis and } \mathrm{O}_{2} \text { utilization. }\end{array}$ & $\begin{array}{l}\text { Repeated sprints }(10 \mathrm{~s} \text { all- } \\
\text { out, } 20 \mathrm{~s} \text { recovery }) \text { and } \\
\text { simulated team sprint }(3 \times 3 \\
\text { min all-out) on a double } \\
\text { poling ergometer in } \\
\text { normoxia or normobaric } \\
\text { hypoxia after training (6 } \\
\text { sessions of double-poling } \\
\text { sprint, } 2 \text { weeks) }\end{array}$ & $\begin{array}{l}\text { Larger improvement in repeated } \\
\text { sprint performance in hypoxic } \\
\text { conditions than normal } \\
\text { conditions with significant } \\
\text { molecular adaptations and larger } \\
\text { blood perfusion variations in } \\
\text { active muscles. }\end{array}$ & $\begin{array}{l}\Delta \mathrm{tHb} \\
\Delta \mathrm{HHb} \\
\Delta \mathrm{O} 2 \mathrm{Hb} \\
\mathrm{mVO} 2\end{array}$ & $\begin{array}{l}\text { Oxymon } \\
\text { MkIII }\end{array}$ \\
\hline Vastus lateralis & $\begin{array}{l}\text { Formenti et al. } \\
(2019)^{37}\end{array}$ & $\begin{array}{l}9 \text { different levels cyclists } \\
(6 \mathrm{M}, 3 \mathrm{~F}, 29 \pm 11 \text { years; } \\
62 \pm 10 \mathrm{~kg})\end{array}$ & $\begin{array}{l}\text { To Investigate changes determined by } \\
\text { increased cadence on skeletal muscle } \\
\text { oxygenation during cycling at an }\end{array}$ & $\begin{array}{l}\text { Exercises at a constant power } \\
\text { output equal to ventilatory } \\
\text { threshold, pedalling at }\end{array}$ & $\begin{array}{l}\text { The significant decrease in } \Delta \text { TSI } \\
\text { at increased cadence recorded in } \\
\text { this study suggests that skeletal } \\
\text { muscle oxygenation is relatively }\end{array}$ & $\begin{array}{l}\text { TSI, } \Delta \mathrm{tHb}, \\
\Delta \mathrm{HHb} \\
\Delta \mathrm{O} 2 \mathrm{Hb}\end{array}$ & $\begin{array}{l}\text { PortaMon } \\
\text { ® }\end{array}$ \\
\hline
\end{tabular}




\begin{tabular}{|c|c|c|c|c|c|c|c|}
\hline & & & $\begin{array}{l}\text { exercise intensity equal to the } \\
\text { ventilatory threshold. }\end{array}$ & $\begin{array}{l}\text { cadences of } 40,50,60,70,80 \\
\text { and } 90 \mathrm{rpm} \text {, each for } 4 \mathrm{~min} .\end{array}$ & $\begin{array}{l}\text { more affected by high cadence } \\
\text { when exercise intensity is close to } \\
\text { Tvent. }\end{array}$ & & \\
\hline Vastus Lateralis & $\begin{array}{l}\text { Gendron et al. } \\
(2016)^{30}\end{array}$ & $\begin{array}{l}10 \text { trained mountain } \\
\text { bikers }(\mathrm{M}, 35 \pm 8 \text { years, } \\
74 \pm 8 \mathrm{~kg})\end{array}$ & $\begin{array}{l}\text { To evaluate the impact of supra- } \\
\text { maximal interval training on different } \\
\text { physiological parameters. }\end{array}$ & $\begin{array}{l}\text { Incremental cycling } r \text { test } \\
\text { before and } \text { after } \\
\text { supramaximal interval } \\
\text { training program. }\end{array}$ & $\begin{array}{l}\text { Lower deoxygenation during } \\
\text { submaximal stages of the test } \\
\text { after training }\end{array}$ & $\begin{array}{l}\Delta \mathrm{tHb}, \\
\Delta \mathrm{HHb} \\
\Delta \mathrm{O} 2 \mathrm{Hb}\end{array}$ & $\begin{array}{l}\text { PortaMon } \\
\circledR\end{array}$ \\
\hline Vastus lateralis & Hamlin et al. $(2010)^{31}$ & $\begin{array}{l}9 \quad \text { highly trained } \\
\text { competitive endurance- } \\
\text { athletes }(7 \mathrm{M}, 2 \mathrm{~F}, 33 \pm 10 \\
\text { years, } 72 \pm 17 \mathrm{~kg})\end{array}$ & $\begin{array}{l}\text { To evaluate the effects of intermittent } \\
\text { hypoxic exposure on cerebral and } \\
\text { muscle oxygenation, arterial oxygen } \\
\text { saturation, and respiratory gas } \\
\text { exchange during a } 20-\mathrm{km} \text { cycle time } \\
\text { trial. }\end{array}$ & $\begin{array}{l}20-\mathrm{km} \text { cycle time trial after } 10 \\
\text { days exposure of hypoxia or } \\
\text { normoxia conditions. }\end{array}$ & $\begin{array}{l}\text { Reductions in muscle oxy- } \mathrm{Hb} \\
\text { and systemic } \mathrm{SaO} 2 \text { occurring at } \\
\text { exercise intensities close to } \\
\text { maximal at the end of a } 20 \mathrm{~km} \\
\text { time trial were offset by hypoxia, } \\
\text { although this was not translated } \\
\text { into improved performance. }\end{array}$ & $\begin{array}{l}\text { TOI, } \Delta \mathrm{tHb}, \\
\Delta \mathrm{HHb} \\
\Delta \mathrm{O} 2 \mathrm{Hb}\end{array}$ & NIRO-200 \\
\hline Vastus lateralis & Hopker et al. (2016) ${ }^{32}$ & $\begin{array}{l}14 \text { well-trained cyclists } \\
(7 \mathrm{M}, 2 \mathrm{~F}, 33 \pm 10 \text { years, } 72 \\
\pm 17 \mathrm{~kg}\end{array}$ & $\begin{array}{l}\text { To investigate the effects of prolonged } \\
\text { constant load cycling exercise on } \\
\text { cycling efficiency and local muscle } \\
\text { oxygen uptake responses. }\end{array}$ & $\begin{array}{l}\text { 2-h steady-state cycling bout } \\
\text { at } 60 \% \text { of their maximal } \\
\text { minute power output. }\end{array}$ & $\begin{array}{l}\text { Gross Efficiency (GE) decreases } \\
\text { and } \mathrm{mVO} 2 \text { increases during } \\
\text { prolonged constant load cycling } \\
\text { exercise a, suggestive of } \\
\text { progressive mitochondrial or } \\
\text { contractile inefficiency. }\end{array}$ & $\begin{array}{l}\text { TSI, } \Delta \mathrm{tHb} \\
\Delta \mathrm{HHb} \\
\Delta \mathrm{O} 2 \mathrm{Hb} \\
\mathrm{mVO} 2\end{array}$ & $\begin{array}{l}\text { PortaMon } \\
\text { (B) }\end{array}$ \\
\hline Vastus Lateralis & $\begin{array}{lll}\text { Iannetta } & \text { et } & \text { al. } \\
(2017)^{24} & & \end{array}$ & $\begin{array}{l}15 \text { trained individuals: } \\
10 \quad \text { cylists, } 5 \\
\text { thriathles/runners }(11 \\
\mathrm{M}, 30.5 \pm 8.4 \text { year; } 76.5 \pm \\
8.4 \mathrm{~kg}-4 \mathrm{~F}, 30.5 \pm 5.9 \\
\text { year; } 61.9 \pm 4.4 \mathrm{Kg})\end{array}$ & $\begin{array}{l}\text { To examine the repeatability of the } \\
{[\mathrm{HHb}] \text { breaking point }([\mathrm{HHb}] \mathrm{BP}) \text { and }} \\
\text { its association to respiratory } \\
\text { compensation point during a ramp } \\
\text { incremental cycling test. }\end{array}$ & $\begin{array}{l}\text { Gas exchange and NIRS } \\
{[\mathrm{HHb}] \text { data were collected }} \\
\text { during ramp incremental } \\
\text { tests performed on two } \\
\text { different days separated by } \\
48 \mathrm{~h} \text {. The [HHb] breaking } \\
\text { point and the respiratory } \\
\text { compensation point were } \\
\text { determined and compared } \\
\text { for each trial. }\end{array}$ & $\begin{array}{l}\text { The }[\mathrm{HHb}] \mathrm{BP} \text { is a repeatable } \\
\text { measure that consistently occurs } \\
\text { towards the end of a ramp } \\
\text { incremental test and associated } \\
\text { with respiratory compensation } \\
\text { point. }\end{array}$ & $\Delta \mathrm{HHb}$ & Oxiplex TS \\
\hline Vastus lateralis & Jacobs et al. $(2013)^{6}$ & $\begin{array}{l}14 \quad \text { trained } \\
\text { cyclists/triathletes }(30.1 \\
\pm 5.3 \text { years; } 74.8 \pm 7.7 \mathrm{~kg})\end{array}$ & $\begin{array}{l}\text { To compare } 3 \text { cycling cadences in } \\
\text { efficiency/economy, local tissue } \\
\text { oxygen saturation, heart rate, blood } \\
\text { lactate, and global and local rating of } \\
\text { perceive } \backslash \mathrm{d} \text { exertion (RPE). }\end{array}$ & $\begin{array}{l}\text { Three 8-minute cadence } \\
\text { trials }(60,80 \text {, and } 100 \mathrm{rpm}) \text { at } \\
75 \% \text { of previously measured } \\
\text { peak power. }\end{array}$ & $\begin{array}{l}\text { Local tissue oxygen saturation } \\
\text { levels are higher at } 80 \mathrm{rpm} \text { than } \\
60 \text { and } 100 \mathrm{rpm} \text {. Cadence of } 60 \\
\text { rpm may be advantageous for } \\
\text { performance in moderately } \\
\text { trained athletes in contrast to } \\
\text { higher cadences currently } \\
\text { popular among elite cyclists. }\end{array}$ & $\Delta \mathrm{SmO} 2$ & $\begin{array}{l}\text { Inspectra } \\
\text { StO2 } \\
\text { Tissue } \\
\text { Oxygenati } \\
\text { on } \\
\text { Monitor }\end{array}$ \\
\hline
\end{tabular}




\begin{tabular}{|c|c|c|c|c|c|c|c|}
\hline Vastus Medialis & Neary et al. (2002) ${ }^{33}$ & $\begin{array}{l}8 \text { cyclists (M } 23 \pm 5 \text { years, } \\
70.4 \pm 4.2 \mathrm{~kg})\end{array}$ & $\begin{array}{l}\text { To evaluate central and peripheral } \\
\text { adaptations related to } \mathrm{VO}_{2} \text { max } \\
\text { improvement after short term high } \\
\text { intensity cycling training }\end{array}$ & $\begin{array}{l}\text { Stepwise incremental } \\
\text { VO2max test and a simulated } \\
20-\mathrm{km} \text { time trial (20TT) } \\
\text { performed on separate days } \\
\text { before and after 3-wk } \\
\text { endurance training. }\end{array}$ & $\begin{array}{l}\text { The significant improvement in } \\
\text { VO2max induced by short-term } \\
\text { endurance training in well- } \\
\text { trained cyclists was due } \\
\text { primarily to central adaptations, } \\
\text { whereas the simulated } 20 \mathrm{~km} \\
\text { time trial performance was } \\
\text { enhanced due to localized } \\
\text { changes in muscle oxygenation. }\end{array}$ & $\begin{array}{l}\Delta \mathrm{HHb} \\
\Delta \mathrm{O} 2 \mathrm{Hb}\end{array}$ & RunMan \\
\hline Vastus lateralis & $\begin{array}{l}\text { Racinais et al. } \\
(2014)^{25}\end{array}$ & $\begin{array}{l}25 \text { cyclists }(\mathrm{M}, 37 \pm 8 \\
\text { years, } 78 \pm 13 \mathrm{~kg})\end{array}$ & $\begin{array}{l}\text { To locate the break points of cerebral } \\
\text { and muscle oxygenation and muscle } \\
\text { electrical activity during a ramp } \\
\text { exercise in reference to the first and } \\
\text { second ventilatory thresholds. }\end{array}$ & $\begin{array}{l}\text { Maximal ramp test on an } \\
\text { electromagnetically braked } \\
\text { cycle-ergometer with a rate } \\
\text { of increment of } 25 \mathrm{~W} / \mathrm{min} \text {. }\end{array}$ & $\begin{array}{l}\text { Non-linear deoxygenation } \\
\text { responses around the second } \\
\text { metabolic threshold. }\end{array}$ & $\begin{array}{l}\Delta \mathrm{HHb}, \\
\Delta \mathrm{O} 2 \mathrm{Hb}\end{array}$ & $\begin{array}{l}\text { Oxymon } \\
\text { MkIII }\end{array}$ \\
\hline Vastus lateralis & Raleigh et al. $(2018)^{26}$ & $\begin{array}{l}31 \text { competitive athletes } \\
(\mathrm{M}, 29 \pm 9 \text { years, } 77.7 \pm \\
10.0 \mathrm{~kg})\end{array}$ & $\begin{array}{l}\text { To compare lactate threshold (TLac) } \\
\text { with non-invasive markers of an } \\
\text { aerobic-anaerobic transition; namely, } \\
\text { ventilatory and tissue saturation index } \\
\text { thresholds. }\end{array}$ & $\begin{array}{l}\text { Graded incremental cycling } \\
\text { to volitional exhaustion. }\end{array}$ & $\begin{array}{l}\text { Non-invasive markers of the } \\
\text { aerobic transition are not } \\
\text { concurrent with TLac. }\end{array}$ & TSI & Moxy \\
\hline Vastus lateralis & Shastri et al. $(2019)^{38}$ & $\begin{array}{l}12 \text { amateur cyclists }(\mathrm{M}, \\
29 \pm 10 \text { years, } 74 \pm 11 \mathrm{~kg})\end{array}$ & $\begin{array}{l}\text { To determine the degree of muscle } \\
\text { oxygenation associated with different } \\
\text { cycling cadences and exercise } \\
\text { intensities. }\end{array}$ & $\begin{array}{l}\text { Steady state cycling at } \\
\text { exercise intensities of } 70 \% \\
\text { and } 90 \% \text { of the ventilatory } \\
\text { threshold for } 4 \text { minutes at } \\
\text { cadence of } 30,50,70,90 \text {, and } \\
110 \mathrm{rpm} \text {. }\end{array}$ & $\begin{array}{l}\text { Skeletal muscle tissue saturation } \\
\text { index is not substantially affected } \\
\text { during cycling for short periods } \\
\text { of time at constant, moderate } \\
\text { exercise intensity at cadences } \\
\text { between } 30 \text { and } 110 \mathrm{rpm} \text {. } \\
\end{array}$ & $\begin{array}{l}\text { TSI, } \Delta \mathrm{tHb}, \\
\Delta \mathrm{HHb} \\
\Delta \mathrm{O} 2 \mathrm{Hb}\end{array}$ & $\begin{array}{l}\text { PortaMon } \\
\text { ® }\end{array}$ \\
\hline $\begin{array}{l}\text { Vastus lateralis - } \\
\text { Vastus Medialis }\end{array}$ & $\begin{array}{l}\text { Skovereng et al. } \\
(2016)^{39}\end{array}$ & $\begin{array}{l}17 \text { recreationally trained } \\
\text { cyclists }(\mathrm{M}, 40 \pm 1 \text { years, } \\
82 \pm 1 \mathrm{~kg})\end{array}$ & $\begin{array}{l}\text { To investigate the effect of cadence on } \\
\text { joint specific power and oxygenation } \\
\text { and local muscle oxygen consumption } \\
\text { in the vastus lateralis and vastus } \\
\text { medialis. }\end{array}$ & $\begin{array}{l}\text { 4-min stages constant load } \\
\text { cycling at different cadences } \\
\text { (from } 60 \text { to } 110 \mathrm{rpm} \text { ) at } 75 \% \\
\text { of work rate at lactate } \\
\text { threshold. }\end{array}$ & $\begin{array}{l}\text { Higher } \mathrm{mVO} 2 \text { (only in vastus } \\
\text { lateralis) and deoxygenation } \\
\text { with increasing cadence. }\end{array}$ & $\begin{array}{l}\text { TSI, } \Delta \mathrm{tHb} \\
\Delta \mathrm{HHb} \\
\Delta \mathrm{O} 2 \mathrm{Hb} \\
\mathrm{mVO} 2\end{array}$ & $\begin{array}{l}\text { Oxymon } \\
\text { MkIII - } \\
\text { PortaMon } \\
\text { (B) }\end{array}$ \\
\hline Vastus lateralis & Sperlich et al. $(2014)^{34}$ & $\begin{array}{l}7 \text { Trained cyclists }(\mathrm{M}, 27 \\
\pm 2 \text { years, } 75 \pm 9 \mathrm{~kg})\end{array}$ & $\begin{array}{l}\text { To determine whether repeated } \\
\text { maximal voluntary apnea enhances the } \\
\text { performance of cyclists in a subsequent } \\
\text { 4-km time trial. }\end{array}$ & $\begin{array}{l}\text { Time trial ( } 4 \mathrm{~km} \text { at maximal } \\
\text { capacity) on own racing bike } \\
\text { with and without apnea. }\end{array}$ & $\begin{array}{l}\text { Similar changes in muscle } \\
\text { oxygenation as with normal } \\
\text { breathing. }\end{array}$ & $\begin{array}{l}\mathrm{TSI}, \\
\Delta \mathrm{HHb}, \\
\Delta \mathrm{O} 2 \mathrm{Hb}\end{array}$ & $\begin{array}{l}\text { PortaMon } \\
\text { ® }\end{array}$ \\
\hline Vastus lateralis & et al. & $\begin{array}{l}6 \text { active healthy } \\
\text { individuals }(M, 28.7 \pm \\
6.0 \text { years, } 66.3 \pm 3.8 \mathrm{~kg}), 6 \\
\text { triathletes }(\mathrm{M}, 21.2 \pm 1.2 \\
\text { years, } 67.2 \pm 5.5 \mathrm{~kg}) \text { and }\end{array}$ & $\begin{array}{l}\text { To investigate the effects of cycling } \\
\text { experience and pedal cadence on the } \\
\text { NIRS parameters }\end{array}$ & $\begin{array}{l}\text { Pedalling exercises at a work } \\
\text { intensity of } 75 \% \text { VO2max } \\
\text { while changing pedal } \\
\text { cadence }(50,75,85 \text {, and } 95 \\
\text { rpm). }\end{array}$ & $\begin{array}{lr}\text { Cycling experience } & \text { and pedal } \\
\text { cadence produce } & \text { detectable } \\
\text { metabolic and circulatory } \\
\text { dynamics changes. }\end{array}$ & $\begin{array}{l}\mathrm{HHb} \\
\Delta \mathrm{O} 2 \mathrm{Hb}\end{array}$ & HEO-100 \\
\hline
\end{tabular}




\begin{tabular}{|c|c|c|c|c|c|c|c|}
\hline & & $\begin{array}{l}6 \text { cyclists }(\mathrm{M}, 30.0 \pm 9.5 \\
\text { years, } 65.3 \pm 8.6 \mathrm{~kg})\end{array}$ & & & & & \\
\hline Vastus lateralis & Turner et al. (2013) ${ }^{35}$ & $\begin{array}{l}16 \text { highly trained } \\
\text { competitive cyclists }(\mathrm{M}, \\
24 \pm 5 \text { years, } 76.7 \pm 7.7 \\
\mathrm{~kg})\end{array}$ & $\begin{array}{l}\text { To determine the effect of inspiratory } \\
\text { loading on limb locomotor and } \\
\text { respiratory muscle deoxygenation } \\
([\text { deoxy }(\mathrm{Hb}+\mathrm{Mb})]) \text { using NIRS during } \\
\text { constant-power cycling exercise. }\end{array}$ & $\begin{array}{l}\text { Maximal incremental cycling } \\
\text { ergometer test. }\end{array}$ & $\begin{array}{l}\text { An increase in respiratory } \\
\text { muscle load increases muscle } \\
\text { deoxy }(\mathrm{Hb}+\mathrm{Mb}) \text { and thus may } \\
\text { indicate a reduction in oxygen } \\
\text { delivery and/or increased } \\
\text { oxygen extraction by the active } \\
\text { muscle. }\end{array}$ & $\begin{array}{l}\Delta \mathrm{HHb}, \\
\Delta \mathrm{O} 2 \mathrm{Hb}\end{array}$ & $\begin{array}{l}\text { ISS } \\
\text { oximeter } \\
\text { Model } \\
96208\end{array}$ \\
\hline Vastus lateralis & $\begin{array}{l}\text { VanDerZwaard et al. } \\
(2016)^{27}\end{array}$ & $\begin{array}{l}10 \text { trained cyclists }(\mathrm{M}, 23 \\
\pm 3 \text { years, } 79.2 \pm 5.2 \mathrm{~kg}) \\
10 \text { trained cyclists }(\mathrm{F}, 24 \\
\pm 4 \text { years, } 63.6 \pm 4.2), 11 \\
\text { endurance trained }(\mathrm{M}, \\
23 \pm 2 \text { years, } 80.5 \pm 7.1 \\
\mathrm{~kg}) \text { and } 9 \text { recreationally } \\
\text { trained }(\mathrm{M}, 24 \pm 2 \text { years, } \\
81.2 \pm 10.3 \mathrm{~kg})\end{array}$ & $\begin{array}{l}\text { To detect an oxygenation breakpoint } \\
\text { and compare this breakpoint to } \\
\text { ventilatory thresholds during a } \\
\text { maximal incremental test across sexes } \\
\text { and training status and to assess } \\
\text { reproducibility of NIRS signals and } \\
\text { exercise thresholds and investigate } \\
\text { confounding effects of adipose tissue } \\
\text { thickness on NIRS measurements. }\end{array}$ & $\begin{array}{l}\text { Maximal incremental cycling } \\
\text { ergometer test. }\end{array}$ & $\begin{array}{l}\text { Although the oxygenation } \\
\text { threshold is reproducible and } \\
\text { potentially a suitable exercise } \\
\text { threshold, VT1 discriminates } \\
\text { better across sexes and training } \\
\text { status during maximal stepwise } \\
\text { incremental } \\
\text { Continuous-waver exercise. } \\
\text { measurements are reproducible, } \\
\text { but strongly affected by adipose } \\
\text { tissue thickness. }\end{array}$ & $\begin{array}{l}\triangle \mathrm{HHb} \\
\triangle \mathrm{O} 2 \mathrm{Hb} \\
\Delta \mathrm{SmO} 2\end{array}$ & $\begin{array}{l}\text { PortaMon } \\
\text { ( }\end{array}$ \\
\hline Vastus lateralis & $\begin{array}{l}\text { Wittekind et al. } \\
(2012)^{36}\end{array}$ & $\begin{array}{lll}8 \text { trained cyclists } & \text { or } \\
\text { triathletes }(\mathrm{M}, \quad 33 & \pm 9 \\
\text { years, } 78 \pm 7 \mathrm{~kg}) & & \end{array}$ & $\begin{array}{l}\text { To investigate the effects of warm-up } \\
\text { intensity on all-out sprint cycling } \\
\text { performance }\end{array}$ & $\begin{array}{l}\text { All-out cycling performance } \\
\text { test of } 30 \mathrm{~s} \text { with different } \\
\text { warm-up intensities. }\end{array}$ & $\begin{array}{l}\text { Similar increasing muscle } \\
\text { oxygenation with all warmups. }\end{array}$ & $\begin{array}{l}\text { TOI, } \Delta \mathrm{tHb}, \\
\Delta \mathrm{HHb} \\
\Delta \mathrm{O} 2 \mathrm{Hb}\end{array}$ & NIRO-200 \\
\hline Vastus lateralis & Zorgati et al. (2015) ${ }^{28}$ & $\begin{array}{l}9 \text { competitive triathletes } \\
(\mathrm{M}, 25 \pm 2 \text { years, } 68 \pm 1 \\
\mathrm{kg}) \text { vs. } 9 \text { untrained } \\
\text { controls }(\mathrm{M}: 21 \pm 3 \text { years, } \\
72 \pm 6 \mathrm{~kg})\end{array}$ & $\begin{array}{l}\text { To compare the muscle oxygenation } \\
\text { between trained and untrained subjects } \\
\text { during heavy exercise until exhaustion } \\
\text { at two extreme pedalling cadences } \\
\text { using a NIRS system. }\end{array}$ & $\begin{array}{l}\text { Cycling test at } 90 \% \text { maximal } \\
\text { power output to exhaustion } \\
\text { at two extreme pedalling } \\
\text { cadences ( } 40 \text { and } 100 \mathrm{rpm}) \text {. }\end{array}$ & $\begin{array}{l}\text { No differences in muscle } \\
\text { deoxygenation in triathletes. }\end{array}$ & $\begin{array}{l}\Delta \mathrm{tHb} \\
\Delta \mathrm{HHb} \\
\Delta \mathrm{O} 2 \mathrm{Hb}\end{array}$ & $\begin{array}{l}\text { Oxymon } \\
\text { MkIII }\end{array}$ \\
\hline
\end{tabular}


Table 3. PEDro scale quality assessmen

\begin{tabular}{lccccccccccccc}
\hline Study (year) & 1 & 2 & 3 & 4 & 5 & 6 & 7 & 8 & 9 & 10 & 11 & score & rating \\
\hline Batterson et al. (2020) & yes & 0 & 0 & 0 & 0 & 0 & 1 & 0 & 1 & 1 & 1 & 5 & Medium \\
Boone et al. (2010) & yes & 0 & 0 & 0 & 0 & 0 & 1 & 0 & 1 & 1 & 1 & 5 & Medium \\
Crum et al. (2017) & yes & 0 & 0 & 0 & 0 & 0 & 1 & 0 & 1 & 1 & 1 & 5 & Medium \\
Faiss et al. (2013) & yes & 1 & 0 & 1 & 0 & 0 & 1 & 1 & 1 & 1 & 1 & 8 & High \\
Formenti et al. (2019) & yes & 1 & 0 & 0 & 0 & 0 & 1 & 0 & 1 & 1 & 1 & 5 & Medium \\
Gendron et al. (2016) & yes & 0 & 0 & 0 & 0 & 0 & 1 & 0 & 1 & 1 & 1 & 5 & Medium \\
Hamlin et al. (2010) & yes & 1 & 0 & 1 & 0 & 0 & 1 & 1 & 1 & 1 & 1 & 8 & High \\
Hopker et al. (2016) & yes & 0 & 0 & 0 & 0 & 0 & 1 & 0 & 1 & 1 & 1 & 5 & Medium \\
Iannetta et al. (2017) & yes & 0 & 0 & 0 & 0 & 0 & 1 & 0 & 1 & 1 & 1 & 5 & Medium \\
Jacobs et al. (2013) & yes & 0 & 0 & 0 & 0 & 0 & 1 & 0 & 1 & 1 & 1 & 5 & Medium \\
Neary et al. (2002) & yes & 0 & 0 & 0 & 0 & 0 & 1 & 0 & 1 & 1 & 1 & 5 & Medium \\
Racinais et al. (2014) & yes & 0 & 0 & 0 & 0 & 0 & 1 & 0 & 1 & 1 & 1 & 5 & Medium \\
Raleigh et al. (2018) & yes & 0 & 0 & 0 & 0 & 0 & 1 & 0 & 1 & 1 & 1 & 5 & Medium \\
Shastri et al. (2019) & yes & 1 & 0 & 0 & 0 & 0 & 1 & 0 & 1 & 1 & 1 & 5 & Medium \\
Skovereng et al. (2016) & yes & 1 & 0 & 0 & 0 & 0 & 1 & 0 & 1 & 1 & 1 & 5 & Medium \\
Sperlich et al. (2014) & yes & 1 & 0 & 0 & 0 & 0 & 1 & 0 & 1 & 1 & 1 & 5 & Medium \\
Takaishi et al. (2002) & yes & 1 & 0 & 0 & 0 & 0 & 1 & 0 & 1 & 1 & 1 & 5 & Medium \\
Turner et al. (2013) & yes & 1 & 0 & 0 & 0 & 0 & 1 & 0 & 1 & 1 & 1 & 5 & Medium \\
VanDerZwaard et & al. & & & & & & & & & & & & \\
(2016) & yes & 1 & 0 & 0 & 0 & 0 & 1 & 0 & 1 & 1 & 1 & 5 & Medium \\
Wittekind et al. (2012) & yes & 1 & 0 & 0 & 0 & 0 & 1 & 0 & 1 & 1 & 1 & 5 & Medium \\
Zorgati et al. (2015) & yes & 1 & 0 & 0 & 0 & 0 & 1 & 0 & 1 & 1 & 1 & 5 & Medium \\
\hline
\end{tabular}

Table 4. Downs and Black modified checklist quality assessment

\begin{tabular}{|c|c|c|c|c|c|c|c|c|c|c|c|}
\hline Study (year) & 1 & 2 & 3 & 6 & 7 & 11 & 12 & 16 & 18 & 20 & $\begin{array}{l}\text { Total } \\
(/ 10)\end{array}$ \\
\hline Batterson et al. (2020) & Y & $\mathrm{Y}$ & Y & $\mathrm{Y}$ & Y & $\mathrm{U}$ & $\mathrm{U}$ & Y & Y & $\mathrm{Y}$ & 8 \\
\hline Boone et al. (2010) & Y & Y & Y & Y & Y & $\mathrm{U}$ & $\mathrm{U}$ & Y & Y & Y & 8 \\
\hline Crum et al. (2017) & Y & $\mathrm{Y}$ & $\mathrm{Y}$ & Y & Y & $\mathrm{U}$ & $\mathrm{U}$ & $\mathrm{Y}$ & $\mathrm{Y}$ & Y & 8 \\
\hline Faiss et al. (2013) & $\mathrm{Y}$ & Y & $\mathrm{Y}$ & Y & Y & Y & $\mathrm{Y}$ & Y & Y & Y & 10 \\
\hline Formenti et al. (2019) & $\mathrm{Y}$ & Y & $\mathrm{Y}$ & Y & Y & $\mathrm{U}$ & $\mathrm{U}$ & Y & $\mathrm{Y}$ & Y & 8 \\
\hline Gendron et al. (2016) & $\mathrm{Y}$ & Y & $\mathrm{Y}$ & Y & Y & $\mathrm{U}$ & $\mathrm{U}$ & Y & $\mathrm{Y}$ & Y & 8 \\
\hline Hamlin et al. (2010) & $\mathrm{Y}$ & $\mathrm{Y}$ & $\mathrm{Y}$ & Y & Y & $\mathrm{U}$ & $\mathrm{U}$ & $\mathrm{Y}$ & $\mathrm{Y}$ & $\mathrm{Y}$ & 8 \\
\hline Hopker et al. (2016) & Y & Y & $\mathrm{N}$ & Y & Y & $\mathrm{U}$ & $\mathrm{U}$ & Y & $\mathrm{Y}$ & Y & 7 \\
\hline Iannetta et al. (2017) & Y & Y & $\mathrm{Y}$ & Y & Y & $\mathrm{U}$ & $\mathrm{U}$ & Y & $\mathrm{Y}$ & Y & 8 \\
\hline Jacobs et al. (2013) & $\mathrm{Y}$ & Y & $\mathrm{Y}$ & Y & Y & $\mathrm{U}$ & $\mathrm{U}$ & Y & $\mathrm{Y}$ & Y & 8 \\
\hline Neary et al. (2002) & $\mathrm{Y}$ & Y & Y & Y & Y & $\mathrm{U}$ & $\mathrm{U}$ & Y & $\mathrm{Y}$ & $\mathrm{Y}$ & 9 \\
\hline Racinais et al. (2014) & Y & Y & $\mathrm{N}$ & Y & Y & $\mathrm{U}$ & $\mathrm{U}$ & Y & Y & Y & 7 \\
\hline Raleigh et al. (2018) & $\mathrm{Y}$ & Y & $\mathrm{N}$ & Y & Y & $\mathrm{U}$ & $\mathrm{U}$ & Y & $\mathrm{Y}$ & Y & 7 \\
\hline Shastri et al. (2019) & $\mathrm{Y}$ & Y & $\mathrm{Y}$ & Y & Y & $\mathrm{U}$ & $\mathrm{U}$ & Y & Y & Y & 8 \\
\hline Skovereng et al. (2016) & $\mathrm{Y}$ & $\mathrm{Y}$ & $\mathrm{N}$ & Y & Y & $\mathrm{U}$ & $\mathrm{U}$ & Y & $\mathrm{Y}$ & Y & 7 \\
\hline Sperlich et al. (2014) & $\mathrm{Y}$ & Y & $\mathrm{N}$ & Y & Y & $\mathrm{U}$ & $\mathrm{U}$ & Y & $\mathrm{Y}$ & Y & 7 \\
\hline Takaishi et al. (2002) & $\mathrm{Y}$ & $\mathrm{Y}$ & Y & Y & Y & $\mathrm{U}$ & $\mathrm{U}$ & Y & Y & Y & 8 \\
\hline Turner et al. (2013) & Y & $\mathrm{Y}$ & Y & $\mathrm{Y}$ & Y & $\mathrm{U}$ & $\mathrm{U}$ & $\mathrm{Y}$ & $\mathrm{Y}$ & Y & 8 \\
\hline $\begin{array}{l}\text { VanDerZwaard et al. } \\
\text { (2016) }\end{array}$ & Y & Y & Y & Y & $\mathrm{Y}$ & $\mathrm{U}$ & $\mathrm{U}$ & Y & Y & $\mathrm{Y}$ & 8 \\
\hline Wittekind et al. (2012) & $\mathrm{Y}$ & Y & $\mathrm{N}$ & Y & Y & $\mathrm{U}$ & U & Y & Y & Y & 7 \\
\hline Zorgati et al. (2015) & $\mathrm{Y}$ & $\mathrm{Y}$ & $\mathrm{N}$ & Y & Y & $\mathrm{U}$ & $\mathrm{U}$ & Y & Y & Y & 7 \\
\hline
\end{tabular}

